\title{
Temporal variation of over-bank flooding of Wei River and its impact on a riparian wetland in Xi'an, China
}

\author{
Shiying Tian, ${ }^{1}$ Wan Luo, ${ }^{2 *}$ Zhonghua $\mathrm{Jia}^{3}$ and Rajpreet Singh Butalia ${ }^{4}$ \\ ${ }^{1}$ Department of Biological and Agricultural Engineering, North Carolina State University, Box 7625, NCSU Campus, Raleigh, NC 27695, USA \\ ${ }^{2}$ Water Resources Research Institute, Xi'an University of Technology, PO Box 748, Shaanxi 710048, China \\ ${ }^{3}$ Environmental Research Institute, Xi'an University of Technology, PO Box 741, Shaanxi 710048, China \\ ${ }^{4}$ Department of Forestry, North Carolina State University, Box 8001, NCSU Campus, Raleigh, NC 27695, USA
}

\begin{abstract}
:
Over-bank flooding is one of the driving forces controlling ecological integrity of riparian wetlands. Indentifying natural overbank flooding regime and its temporal variations is crucial for developing conservation and restoration plans and making water resources management policies for these ecosystems. Along the midstream of the Wei River in Xi' an, China lies the Jingwei riparian wetland, which was well preserved until the 1970s. Based on historical record of hydrological and morphological data of the Wei River from 1951 to 2000, we analysed temporal variations of over-bank flooding frequency, duration, and timing in this paper. The natural annual over-bank flooding regime was identified as having an occurrence frequency of 2.2 times a year and average duration of $5 \cdot 3$ days; these flooding events typically occur between June and September with occasional occurrence in late spring and late autumn. Over-bank flooding occurrence frequency and duration decreased significantly during the 1990s, seasonal events of over-bank floods were changed through reduced flooding frequency during summer and disappearing flooding events in late spring and late autumn. Further investigations showed that reduced discharge in the Wei River was the principal cause for these changes in over-bank flooding dynamics. Our analysis also showed that decreased discharge of the Wei River during the 1990s was attributed near equally to disturbances from human activities and decreased regional precipitation. Results from this study may help reestablish natural over-bank flooding dynamics in order to ensure successful restoration of Jingwei riparian wetland. Copyright (c) 2010 John Wiley \& Sons, Ltd.
\end{abstract}

KEY WORDS riparian wetlands; over-bank flooding; human activities; climate change; wetland restoration

Received 14 November 2008; Accepted 20 November 2009

\section{INTRODUCTION}

Riparian wetlands, transitional zones between aquatic and upland systems (Mitsch and Gosselink, 2000), are vital to the healthy functioning of the whole river ecosystem. They are inherently connected with adjacent aquatic systems through water-mediated exchanges of energy, nutrients, and species (Heiler, et al., 1995; Tockner et al., 1999; Pringle, 2001). As a determinant driving force for ecological integrity of riparian wetlands, connection with rivers not only supplies significant amount of water, especially in arid and semi-arid areas with insufficient precipitation to sustain wetland hydrology conditions (Puckridge et al., 1998; Amoros and Bornette, 2002), but also provides necessary nutrients, such as nitrogen and phosphorus to riparian wetlands (Junk et al., 1989; Junk and Wantzen, 2004). This connectivity is also a major process controlling plant community composition and distribution (Naiman and Décamps, 1997) and thus influences the biotic diversity of riparian wetland ecosystems.

Connectivity between riparian wetlands and rivers can be achieved through subsurface or surface flows. Subsurface connectivity occurs via groundwater flow. Such

* Correspondence to: Wan Luo, Water Resources Research Institute, Xi' an University of Technology, PO Box 748, Shaanxi 710048, China. E-mail: wluo@mail.xaut.edu.cn interactions may cause major changes in riparian wetlands hydrology, but they had little impact on geomorphological changes (such as accretion and/or erosion), nor do they allow for movement of large organic matter or sediment particles. Surface connectivity via over-bank flooding events enables direct interaction between rivers and riparian wetlands. This connectivity allows strong exchange of dissolved and suspended matter, flora and fauna, and regulates the geomorphological conditions of the whole river ecosystem. Recent studies have showed that temporal surface connectivity plays a critical role in sustaining integrity and biodiversity of riparian wetland ecosystems and potentially influences functions of riverfloodplain ecosystems (Kingsford, 2000; Mitsch and Gosselink, 2000). Surface connectivity can regulate wetland soil, moisture and nutrients (Fennessy and Mitsch, 2001) and control plant community composition and distribution (Rea and Ganf, 1994; Bledsoe and Shear, 2000; Pettit et al., 2001; Robertson et al., 2001; Leyer, 2005; Magee and Kentula, 2005). It may also affect wetland biogeochemical processes (Hamilton et al., 1995; Tockner et al., 1999; Pringle, 2001; Fink and Mitsch, 2007), improve diversity of various vertebrate and invertebrate groups (Tockner et al., 1999), and influence primary production in riparian wetlands (Robertson et al., 2001). Number of scholars have concluded that functions of some riparian 
wetlands are dominantly supported by seasonal surface connectivity (Mitsch and Gosselink, 2000; Robertson et al., 2001). A key concept in emphasizing the importance of surface connectivity is the flood pulse concept (Junk et al., 1989; Junk and Wantzen, 2004), which posits the view that rivers and their fringing floodplain wetlands are integrated components of a single dynamic system, linked by strong hydrological and ecological interactions through surface connectivity. The flood pulse concept has proven to be an integrative approach for studying highly diverse and complex ecological processes in riverfloodplain systems in tropical areas where the theory was developed, as well as in temperate (Tockner et al., 2000; Harold and Michael, 2006) and arid or semi-arid areas (Walker et al., 1995; Puckridge et al., 1998; Amoros and Bornette, 2002).

Like other ecosystems riparian wetlands are vulnerable to local impacts of climate change and human disturbances. Their dependence on adjacent river channels for hydrological and ecologic inputs renders them susceptible to regional changes within the watershed. River flow regime may be changed due to decreased precipitation, increased temperature and human activities in the watershed, such as dam construction, stream channelization, river embankment, flow regulation, and water extraction (Poff et al., 1997; Molles et al., 1998; Davis and Froend, 1999; Page et al., 2005). Variation in connectivity dynamics may lead to degradation of wetland functions and shrinkage of wetland areas, ultimately cause a specific wetland to be replaced by other landscape elements (Galat et al., 1998; Davis and Froend, 1999; Mitsch and Gosselink, 2000; Reckendorfer et al., 2006). Kingsford (2000, 2003) and Kingsford and Thomas (2002) proposed that reductions in frequency and duration of bankfull events can cause a decrease in riparian wetland extent and health.
Due to the importance of over-bank flooding for riparian wetlands, reestablishing lateral surface connectivity between rivers and riparian wetlands is a promising method for restoring riparian wetlands or the whole river ecosystems (Ward and Stanford, 1995; Galat et al., 1998; Molles et al., 1998; Middleton, 1999; Schiemer et al., 1999; Palmer et al., 2005). Investigating natural temporal patterns of over-bank flooding dynamics can provide important information for developing riparian wetland restoration strategies. Studies have shown that the frequency, duration and timing of over-bank flooding can be used to characterize the temporal nature of surface connectivity (Poff et al., 1997; Kingsford, 2000; Robertson et al., 2001; Kingsford and Thomas, 2002; Kingsford, 2003; Reckendorfer et al., 2006). For instance, Robertson et al. (2001) pointed out that frequency of overbank flooding is essential in determining the structure and function of plants communities in many riparian wetlands. Reckendorfer et al. (2006) introduced a connectivity parameter represented by annual duration of over-bank flooding to quantify impact and success of restoration measures. Another important characteristic, over-bank flood timing is ecologically critical for many aquatic and riparian species (Poff et al., 1997) because they are consequential in dispersal of plant propagules, triggering germination and supporting subsequent establishment of seedlings (Naiman and Décamps, 1997; Middleton, 1999; Robertson et al., 2001).

The Wei River is a major tributary of the Yellow River in China. It was joined by the Jing River near $\mathrm{Xi}$ 'an, China. At the confluence of these two rivers lies the well known Jingwei riparian wetland, as shown in Figure 1. This wetland once had a significant coverage and important ecological functions. Since 1970s, however, the natural vegetation of the wetland has been

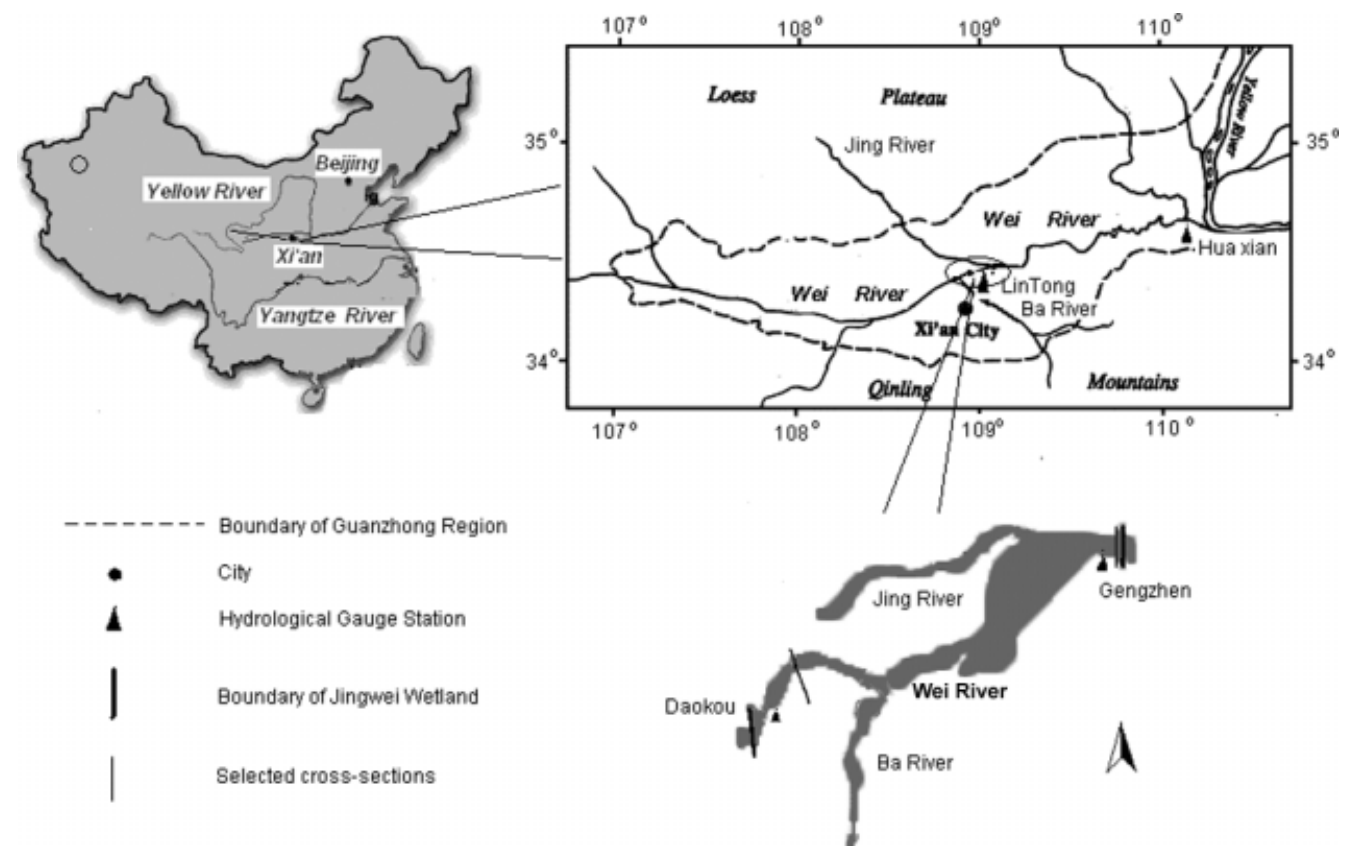

Figure 1. Location of the study area, boundary of Jingwei riparian wetland and selected cross sections 
severely damaged and a large area has lost characteristics of natural wetlands (Tian, 2007). Studies by Jia et al. (2004) and Tian et al. (2008) found that on-site precipitation and subsurface water recharge nowadays are not sufficient to sustain hydrology of the wetland. Thus, exploring the natural over-bank flooding dynamics and temporal variations of over-bank flooding pulses is an essential step toward development of sound conservation and restoration strategies for Jingwei wetland, and investigating the inherent causes of the temporal variations of over-bank flooding is critical for a good understanding of hydrological alterations to make rational water resources management policies.

The main objectives of this study were to: (1) investigate natural dynamics of over-bank flooding in Jingwei wetland and quantitatively evaluate annual and decadal temporal trends and variations; and (2) explore relationships between possible causes and observed temporal patterns. We hypothesized that temporal variations in over-bank flooding can be attributed to flow alteration in the Wei River discharge, which has been affected by climate change and human disturbances. Historical precipitation and river discharge records from 1951 to 2000 were used to test our hypothesis.

\section{STUDY SITE DESCRIPTION}

As shown in Figure 1, Jingwei wetland (Latitude $=$ $34^{\circ} 20^{\prime} \mathrm{N}$, Longitude $=109^{\circ} 49^{\prime} \mathrm{E}$ ) is located at the confluence of the Jing River and the Wei River near Xi' an China. Elevations of the site range from 357 to $373 \mathrm{~m}$. Current land cover types include riparian wetlands, croplands, waste lands and shrub lands. The area has a sub-humid continental climate with annual average temperature of $13.2^{\circ} \mathrm{C}$. Mean annual precipitation is $594.1 \mathrm{~mm}$, with $60 \%$ of the precipitation occurring between July and September. Average annual pan evaporation is $1528.8 \mathrm{~mm}$, which is about 2.6 times the mean annual precipitation (Tian et al., 2008). The area has a frost-free period of 207 days and sunshine hours of 2415 each year. Surficial deposit of the wetland area consists of about $20 \mathrm{~m}$ of loess characterized by sand, sandy loam and sandy clay (Tian et al., 2008). The loess layer is underlain by alluvial deposits of clayey soil inter-bedded with sand. Under the loess layer are Cenozoic deposits with total thickness of 2000-7000 m (Lu et al., 2008).

The original area of Jingwei wetland can not be found in record, but it was claimed to be the largest wetland in the region (Shi, 1999). The natural vegetation of Jingwei wetland has been severely damaged since 1970s, and most of the originally wet area has lost characteristics of natural wetlands (Tian, 2007). The Ministry of Water Resources of China and the government of Xi' an City have initiated a plan to restore the wetland as a first step to protect ecosystem of the Wei River, the largest tributary of the Yellow River in China. The planed area of the restored Jingwei wetland is $63.5 \mathrm{~km}^{2}$.

The Wei River, originating from north of the Wushu Mountains, runs $818 \mathrm{~km}$ through the provinces of Gansu and Shannxi before it joins the Yellow River (Figure 1). It has a total catchment area of about $134800 \mathrm{~km}^{2}$. It contributes $16.5 \%$ annual runoff and $32.5 \%$ annual sediment to the Yellow River. Within our study site, the channel width of the Wei River is between 0.25 and $0.47 \mathrm{~km}$, and the average channel gradient is between $0.45 \%$ and $0.6 \%$. As one of the cradles of early Chinese civilization, the Wei River has been heavily regulated by four large reservoirs and 29 medium sized reservoirs. There are now 32 water diversion projects with a discharge rate of about $6.17 \times 10^{8} \mathrm{~m}^{3}$ year $^{-1}$ (Song et al., 2007). These engineering structures provide water for an irrigated land area of more than $1.1 \times 10^{6}$ ha and other users along the main channel and its tributaries in the region. Annual flow of the Wei River has been observed decreasing sharply at the Lintong gauging station, located in downstream of Jingwei riparian wetland. The river flow has decreased by $53.4 \%$ from $1951-1960$ to $1991-2000$, as illustrated in Figure 2.

\section{MATERIALS AND METHODS}

Morphological, climatic and hydrological data used in our study were obtained from the Yellow River Conservancy Commission (YRCC) that maintains a hydrological

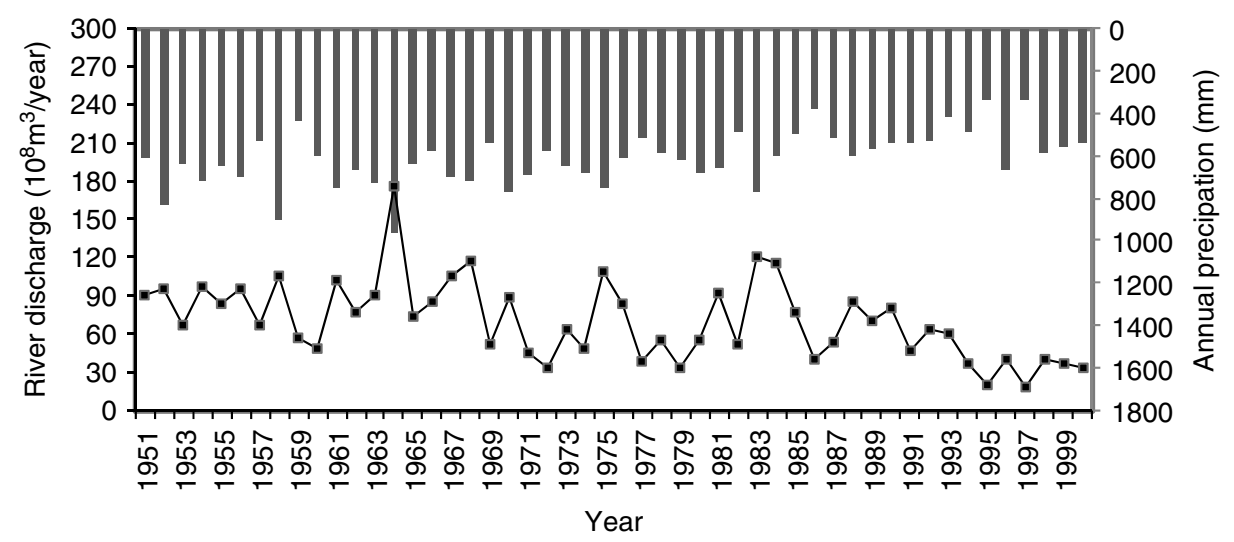

Figure 2. Annual runoff (solid line with markers) of Wei River at Lintong gauge station and annual precipitation (bar) upstream of the station from 1951 to 2000 
monitoring network for the Wei River. The network is comprized of a number of water level and discharge gauging sites and several cross-sectional geometric measurement sites along the river channel. Hydrological measurements were conducted on a daily basis, whereas the cross-sectional geometric records were measured on an annual or semi-annual basis. Two cross sections and three gauging stations along the Wei River with longterm (about 50 years) hydrological and morphological data were selected to conduct our research. Over-bank flooding frequency, duration, and timing were used to characterize over-bank flooding dynamics.

\section{Data collection}

Two cross sections that are $11.7 \mathrm{~km}$ apart located at Daokou and Gengzhen were selected as representative points in this study (Figure 1). These two cross sections are very close to the boundaries of the Jingwei wetland with Daokou on the upstream (western) end and Gengzhen on the downstream (eastern) end. Long-term observations (1969-2000) of cross-sectional morphological data are available for both sections.

About 50 years hydrological data, including river stage and runoff discharge, were available from the nearest gauging stations, which are less than 200-m away from the selected cross sections. At Daokou section, river stage data are available for the period 1951-2000. At Gengzhen section, data were available from two sources: 1979-1998 data from Gengzhen station, which is about $150 \mathrm{~m}$ from the cross section (Figure 1), and 1960-1979 data from Lintong station, which is about $9.9 \mathrm{~km}$ downstream from Gengzhen station. Two data sets were compiled to extend the historical data range. Monthly maximum flood stage data from 1979 to 1985 at both stations were selected to establish a relationship between the two gauge stations to minimize the effect of spatial and temporal variations in morphology. The high correlation coefficient of 0.98 indicates a strong linear relationship between river flood stages at the two stations (Figure 3). Thus, the river stage at Gengzhen station can be predicted with a high degree of certainty from river

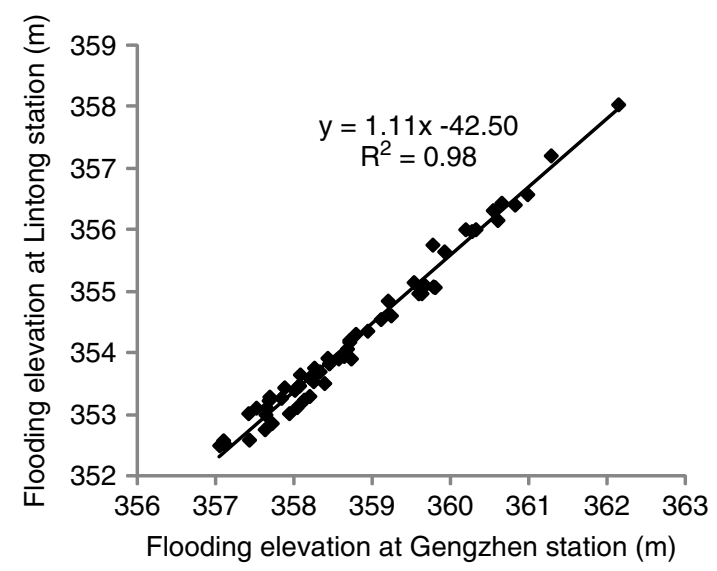

Figure 3. Correlation of flood stages between Gengzhen gauge and Lintong gauge stage data at Lintong station using the linear regression equation presented in Figure 3.

\section{Analysis of the over-bank flooding dynamics}

Determination of over-bank flooding. To avoid uncertainties in estimating bankfull discharge, measured daily river stage and determined yearly bankfull stages of each year were used to identify over-bank flooding events. Identifying bankfull elevation at a given river cross section is usually ambiguous considering various methods proposed for it. Based on a review of definitions for over-bank flooding by Navratil et al. (2006) and available data at our study site, the beginning of the floodplain named top of bank (TOB), was used to determine the surface elevation at bankfull stage. Another reason for choosing this definition is that it is closely associated with the limit of surface connectivity between the main channel and the adjacent riparian wetland. Both cross sections were constructed using topographic data (more than 30 measurement points) measured annually or semi-annually from 1969 to 2000.

Determination of over-bank flooding frequency and duration. Flooding frequency and duration analysis are often conducted with daily river discharge or stage data because of their common availability over longer period of time (Petit and Pauquet, 1997; Sweet and Geratz, 2003; Page et al., 2005). Long-term daily hydrological data were used to identify the natural over-bank flood regime and investigate its temporal variations in this study. Bankfull discharge occurs commonly at a recurrence interval of 1-2 years based on estimation using the annual maximum flood (AMF) approach (Harman et al., 1999; Castro and Jackson, 2001). However, the conclusion has been questioned by other studies (Petit and Pauquet, 1997; Lang et al., 1999) because the AMF approach mathematically gives recurrence intervals more than one year. For shorter recurrence intervals, the bankfull discharge frequency can be analysed by the partial duration series method, which utilizes all independent events that exceed certain threshold (Lang et al., 1999). TOB elevations determined from cross-sectional data for each year were the thresholds in this study. Once an over-bank flooding event was determined, its duration was estimated using the flow duration approach. In order to ensure independence of each over-bank flooding event, a method proposed by the Water Resources Council of United States (USWRC, 1976) was used. As indicated in Equation (1), the method imposes a restriction that successive flood events should be separated by a period that is at least 5 days plus the natural logarithm of square miles of basin area, and the intermediate flows between two consecutive peaks must drop below $75 \%$ of the lesser amount of daily discharge of the two flood events.

$$
d>5 \text { days }+\ln (A) \text { and } Q_{\min }<\frac{3}{4} \min \left[Q_{1}, Q_{2}\right]
$$

where $d$ in days is the intervals of two flooding events, $A$ is the basin area in square miles, $Q_{\min }$ is the minimum 
flow discharge between the two flood events, $Q_{1}$ and $Q_{2}$ in $\mathrm{m}^{3}$ day $^{-1}$ are the daily discharge of the two consecutive peaks, respectively.

The duration of a single over-bank flooding is defined as the period from the time when river discharge exceeds the threshold of discharge to the time when the flood discharge was reduced to $75 \%$ of the threshold (USWRC, 1976), with an assumed minimum duration of 1 day.

Causes of temporal trends and variations in over-bank flooding. Decreased Wei River discharge was hypothesized as the principal cause of changes in over-bank flooding. Page et al. (2005) determined the effects of altered flow regime on frequency and duration of bankfull flows on the Murrumbidgee River in Australia by comparing historical regulated flow to simulated natural flow data. We adopted a similar framework for determining the impacts of alterations in flow, but used simpler modelling tools to determine impacts of alterations in flow. Chezy's equation was used to estimate daily river stage of a dry year (without over-bank flooding) based on daily river discharge of a wet year and a normal year. Note that dry, normal and wet years were randomly selected based on annual runoff of the Wei River. To account for the effects of morphological changes of river channels, cross section of the selected dry year was used to establish river stage-discharge relationship. Thereafter, Pettitt's change point test (Pettitt, 1979) and the double mass curve method were used to separate contributions of human activities and climate change to the decreased Wei River discharge. The Pettitt's test and double mass curve analysis were carried out using data from Lintong station, which is located $9.9 \mathrm{~km}$ downstream of Jingwei riparian wetland as shown in Figure 1.

Application of Chezy's Equation: Chezy's equation was used to establish the relationship between stage and discharge of the selected dry year based on historical flow data and cross-sectional data of the Wei River. Chezy's equation for discharge can be written as (Gerhart et al., 1992):

$$
Q=C A \sqrt{R S}
$$

Where $C$ is Chezy's coefficient, $R$ is hydraulic radius, $S$ is slope of the energy line and $A$ is area of channel cross section.

Substituting $C \sqrt{S}$ with a constant $K$ for the cross section at any stage and approximating $R$ as a mean depth of flow $h$, Equation (2) can be rewritten as:

$$
Q=C A \sqrt{R S}=K A \sqrt{h}
$$

A plot of $Q$ versus $A \sqrt{h}$ now becomes a straight line. The determined relationship between $Q$ and $h$ can be used to predict $h$ using river discharge data series. $K$ values were calibrated by linear regression using measurements of flow (discharge and stage) data and cross-sectional morphological data.
Pettitt's change point test: The non-parametric approach of Pettitt (1979) was used in this study to detect potential change points and calculate their statistical significance. Given a time series $x_{i}(1 \leq i \leq N)$, Pettitt used a version of the Mann-Whitney statistic $U_{t, N}$, which verifies if two samples $x_{1}, \ldots, x_{t}$ and $x_{t+1}, \ldots, x_{N}$ are from the same population. The $U_{t, N}$ statistic counts the number of times a member of the first sample that exceeds a member of the second sample and is given by the following equation:

$$
U_{t, N}=U_{t-1, N}+\sum_{j=1}^{N} \operatorname{sgn}\left(x_{t}-x_{j}\right) \text { for } t=2,3, \ldots, N .
$$

Where $\operatorname{sgn}(X)=1$ if $X>0, \operatorname{sgn}(X)=0$ if $X=0$, and $\operatorname{sgn}(X)=-1$ if $X<0$.

The null hypothesis of Pettitt's test is the absence of a change point. Its statistic $k(t)$ and associated probabilities ( $p$ ) used in significance testing are given by Equations 5 and 6 , respectively.

$$
\begin{aligned}
k(t) & =\max _{1 \leq t \leq N}\left|U_{t, N}\right| \\
p & \cong 2 e^{\left(-6 k(t)^{2} /\left(N^{2}+N^{3}\right)\right)}
\end{aligned}
$$

Pettitt's test was discussed in detail and applied successfully to study climate change by Demaree (1990) and Victoria et al. (1998). This method has also been used to detect hydrological change points (Huo et al., 2008; Zhang et al., 2008).

Double mass curve: The double mass curve method was used to quantify the change in relationship between precipitation and river discharge for different periods identified by Pettitt's change point test. A double mass curve is a plot of cumulative values of one variable against accumulation of another quantity during the same time period (Searcy and Hardison 1960). The theory behind double mass curves is that when the plot of two cumulative quantities is a straight line, the slope of the straight line represents the constant of proportionality between the two quantities, and a break in slope indicates a change in the constant of proportionality (Searcy and Hardison 1960). Although double mass curve analysis is typically performed on precipitation data, it has been used to study the effects of climate change and human activity on variations of watershed runoff (Lørup et al. 1998; Huo et al. 2008) and evaluate soil water conservation projects (Herweg and Ludi, 1999). For our study, runoff data were obtained from Lintong gauge station and precipitation data was obtained from the YRCC, where data were estimated through rainfall data collected at gauge stations that are located at upstream of the Lintong station.

\section{RESULTS}

\section{Bankfull stage and discharge}

Determined bankfull stages of the two cross sections for several typical years are listed in Table I. TOB was 
Table I. Thresholds of bankfull stages $(\mathrm{m})$ at selected cross sections for representative years

\begin{tabular}{lcccccccccc}
\hline Year & 1969 & 1968 & 1973 & 1977 & 1981 & 1986 & 1990 & 1995 & 1997 & 2000 \\
\hline Gengzhen & $359 \cdot 1$ & $359 \cdot 3$ & $359 \cdot 2$ & $359 \cdot 6$ & $359 \cdot 4$ & $359 \cdot 5$ & $359 \cdot 8$ & $359 \cdot 6$ & $359 \cdot 4$ & $359 \cdot 5$ \\
Daokou & $366 \cdot 1$ & $366 \cdot 1$ & $365 \cdot 9$ & $366 \cdot 2$ & $366 \cdot 1$ & $366 \cdot 0$ & $366 \cdot 2$ & $366 \cdot 4$ & $366 \cdot 5$ & $366 \cdot 5$ \\
\hline
\end{tabular}

The threshold stages were estimated based on the river bank elevation taking the sea level as datum

assumed to be constant from 1951 to 1969 , because previous studies have indicated that the river channel at our study site was in erosion-aggradation equilibrium during this period (Wang et al. 2004). From 1969 to 2000 , river bankfull stage elevation at each cross section increased by approximately $0.4 \mathrm{~m}$. According to Deng and Guo (2006), total sediment deposited along the Wei River was $13.09 \times 10^{9} \mathrm{~m}^{3}$ during our study period; but the upper reaches of the Wei River within which we studied only intercepted $2.3 \%$ of the total sediment. Therefore, bankfull stage of the two cross sections did not increase significantly as that in the downstream of the Wei River. The measured threshold bankfull discharge, as listed in Table II, decreased from $5000 \mathrm{~m}^{3} / \mathrm{s}$ before 1966 to $3200 \mathrm{~m}^{3} / \mathrm{s}$ in 2000 at Lintong gauging station, a $36 \%$ reduction in flow rate. Major decline of bankfull discharge occurred after 1980s as listed in Table II. Deng and Guo (2006) attributed bankfull discharge fluctuation to variations in cross-sectional area of the main channel.

\section{Temporal variations of over-bank flooding dynamics}

Variations of over-bank flooding frequency. To examine the trend of over-bank flooding dynamics, we compared over-bank flooding frequency over the studying period based on a pentannual interval. Long-term temporal dynamics of over-bank flooding events at Gengzhen cross section from 1961 to 2000 and Daokou cross section from 1951 to 2000 are presented in Figure 4. Average annual flooding events are 1.91 at Gengzheng cross section and 1.85 at Daokou cross section. Flooding frequency at Gengzhen was slightly higher than that at Daokou cross section, but the difference was insignificant $(p=0 \cdot 45)$. The highest annual frequency for each cross section was $2 \cdot 8$, which occurred during the period of 1961-1965 at Gengzhen cross section and 1956-1960 at Daokou cross section. There was no significant difference between over-bank flooding frequency during the 1980s and before for both cross sections $(p>0 \cdot 18)$. Average annual flooding frequency during the 1990s was 0.8 for Gengzhen and $0 \cdot 3$ for Daokou, both reduced significantly $(p<0.0005)$ comparing to that before 1990. The temporal dynamics of over-bank flooding events were similar at the two cross sections and both had a decreasing trend as shown in Figure 4.
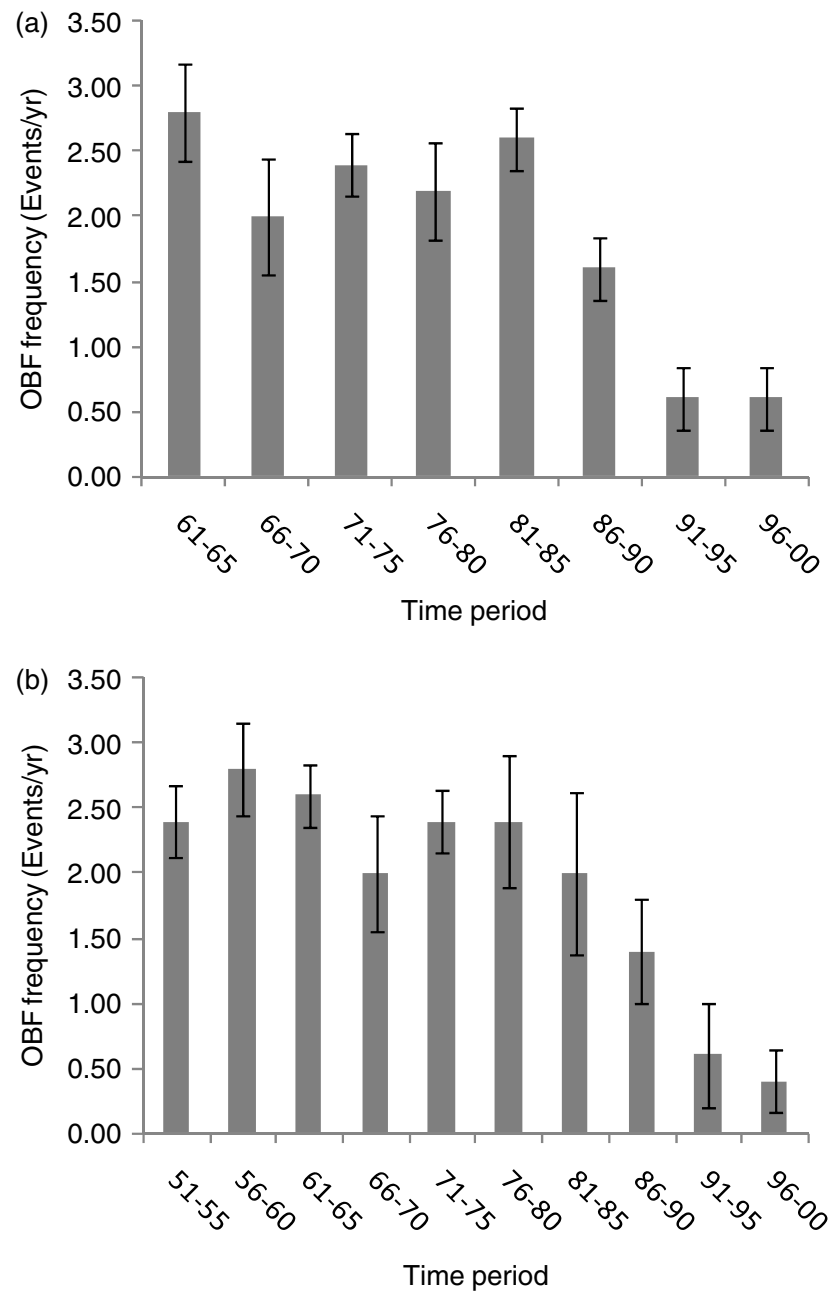

Figure 4. Over-bank flooding (OBF) frequency during different periods at (a) Gengzhen section and (b) Daokou section

Variations of over-bank flooding duration. Figure 5 presents the over-bank flooding durations at the two cross sections based on a pentannual interval. Similar to average over-bank flooding frequency, mean annual over-bank flooding duration was 5.9 days at Gengzhen and 5.1 days at Daokou cross section, and the difference was insignificant at the level of $p=0 \cdot 28$. The longest mean annual over-bank flooding duration was 14.4 days during 1981-1985 at Gengzhen, and 10.2 days during

Table II. Measured bankfull discharge (Q) at Lintong station in representative years (Adapted from Deng and Guo, 2006)

\begin{tabular}{lllllllllll}
\hline Year & 1966 & 1968 & 1973 & 1977 & 1981 & 1986 & 1990 & 1995 & 1997 & 2000 \\
\hline $\mathrm{Q}\left(\mathrm{m}^{3} / \mathrm{s}\right)$ & 5000 & 4850 & 4300 & 4370 & 4670 & 3920 & 3600 & 3520 & 3200 & 3200
\end{tabular}


1971-1975 at Daokou cross section. Mean annual overbank flooding duration before 1985 was 7.2 days at Gengzhen and 5.6 days at Daokou cross section. No significant differences $(p>0 \cdot 2)$ were detected between over-bank flooding durations in the 1980s and the time before at both cross sections. The mean annual over-bank flooding duration before 1990 was 7.3 days at Gengzhen and 5.8 days at Daokou cross sections, which were reduced to 1.2 days in 1990 at Gengzhen and 0.7 days in 2000 at Daokou, both were reduced significant at a level of $p<0.0005$.

Seasonal variations of over-bank flooding. Seasonal variations of over-bank flooding were evaluated by summarizing flooding events by month during the growing season from May to October at a decadal interval. Only one flooding event that occurred in April during 1980s at Daokou cross section was excluded from this analysis. As shown in Figure 6, monthly average flooding events from May to October were 2.8, 1.3, 4.3, 2.3, 5.3, and $2 \cdot 8$ at Gengzhen cross section and $2 \cdot 4,1 \cdot 6,4 \cdot 4,2 \cdot 6,4 \cdot 8$, and 1.8 at Daokou cross section. Seasonal variations of over-bank flooding at the two cross sections were very similar. At each cross section, $65 \%$ of total over-bank flooding events occurred in summer from July to September, and 30\% occurred in May (spring) and October (late summer). Similar to over-bank flooding frequency and
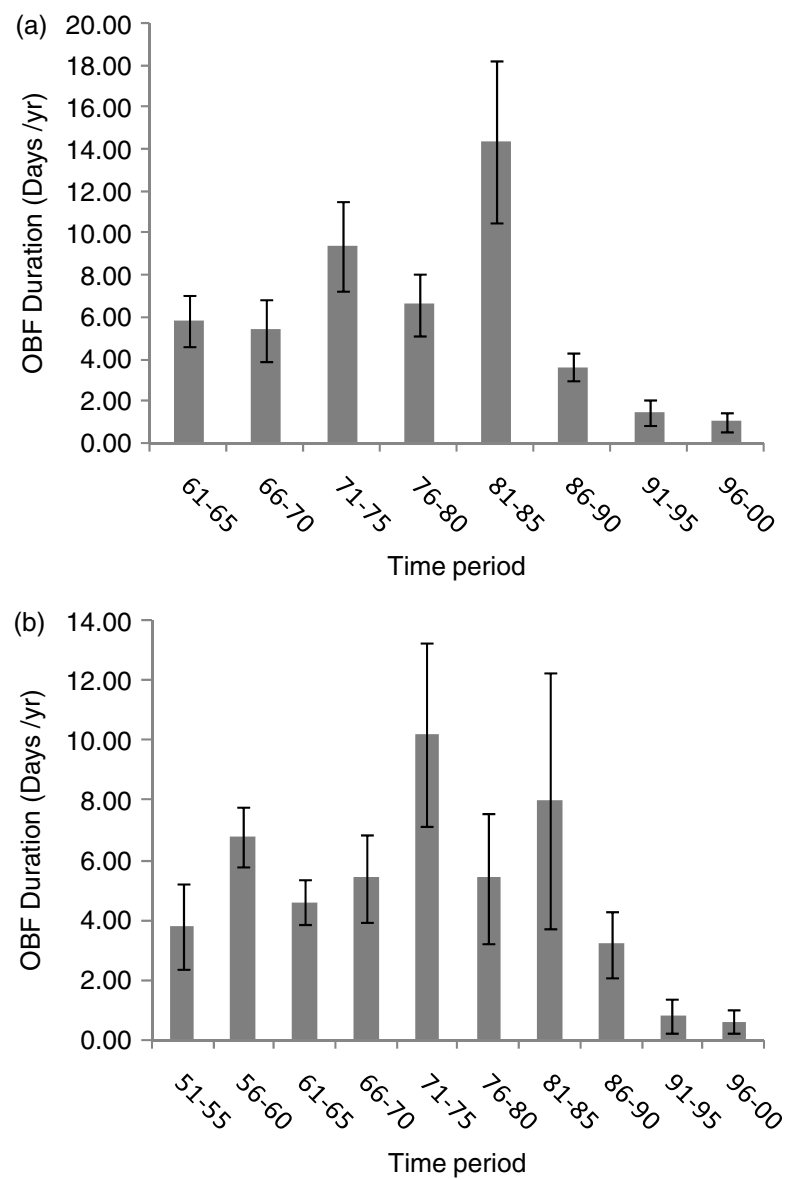

Figure 5. Over-bank flooding (OBF) duration during different periods at (a) Gengzhen section and (b) Daokou section duration, monthly flooding events from May to October during the 1990s decreased significantly $(p<0.05)$ at both cross sections, except in July at Gengzhen cross section at $p=0 \cdot 42$. For example, no over-bank flooding occurred in May and September at Gengzhen cross section and no flooding event in June and October at Daokou cross section for the period 1990-2000. At both cross sections, almost no over-bank flooding events occurred in late spring and late autumn during the period of 1990-2000, except one in October at Gengzheng cross section and one in May at Daokou cross section.

\section{DISCUSSIONS}

Effects of alteration in river flow regime on changes of over-bank flooding

The above analyses indicated that surface connectivity between the Wei River and Jingwei riparian wetland has changed significantly, especially after 1990. Previous studies have demonstrated that altered river flow regime and channel morphological are two major factors for variations in over-bank flooding dynamics (Wurster $e t$ al., 2003; Page et al., 2005). Ward and Stanford (1995) pointed out that magnitude of peak flooding could be reduced significantly by river regulations, which in turn lead to decreased floodplain inundation frequency and extent. Studies by Page et al. (2005) showed that flow regulation could be a main cause for variability in frequency and duration of over-bank flooding. In an extensive review of the effect of dams on flow regime and channel morphology, Petts and Gurnell (2005) concluded
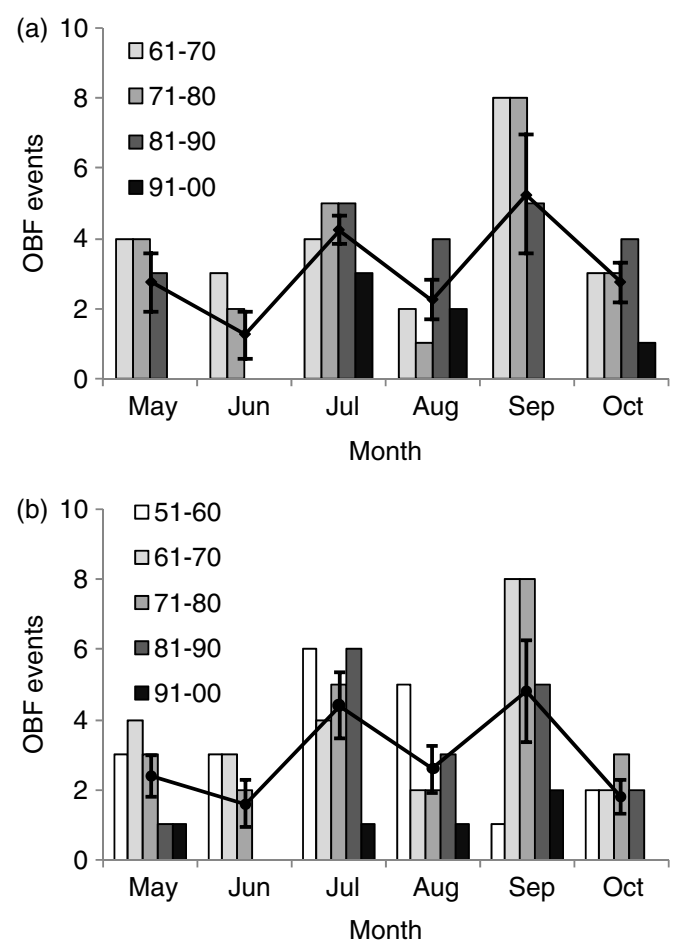

Figure 6. Decadal aggregated monthly over-bank flooding (OBF) events from May to October at cross section of (a) Gengzhen and (b) Daokou. Line indicates average flooding events of each month 
that the flow regulation caused by dams can lead to marked reduction in bankfull flow frequency. Measured bankfull discharge of Lintong gauging station decreased dramatically since 1980s (Table II). This was attributed to river channel shrinkage in the study by Deng and Guo (2006). The over-bank flooding frequency and duration should increase accordingly if there was no significant change in river flow regime. Such a postulation, however, contradicts to our findings in this study. Changed river flow regime (Figure 2) was hypothesized as the principal cause for temporal variations in over-bank flooding dynamics in an early section of this paper. We tested this hypothesis by estimating over-bank flooding dynamics for a dry year with no over-bank flooding using daily discharge of a normal and a wet year via an established discharge-stage relationship using Chezy's equation.

Selection of representative years. Based on annual runoff of the Wei River, 1999, 1973, and 1981 were selected as the representative dry, normal and wet years. No over-bank flooding occurred in 1999, while two flooding events occurred in 1973 and three floodings in 1981. Summarized hydrological quantities of the 3 years are listed in Table III. Using Chezy's equation, a stagedischarge relationship for Gengzhen cross section was established for 1999 based on geomorphological and hydrological data of that year. River stages were then estimated with the established stage-discharge relationship for 1973 and 1981 using mean daily discharge of 1973 and 1981 (Figure 7). Estimated daily stages were compared to the TOB elevation of 1999 to determine flood

Table III. Hydrologic elements of Gengzhen cross section of selected water year

\begin{tabular}{cccccc}
\hline $\begin{array}{c}\text { Precipitation } \\
(\mathrm{mm})\end{array}$ & $\begin{array}{c}\text { Annual } \\
\text { runoff } \\
\left(10^{8} \mathrm{~m}^{3}\right)\end{array}$ & $\begin{array}{c}\text { Threshold } \\
\text { stage }(\mathrm{m})^{\mathrm{a}}\end{array}$ & $\begin{array}{c}\text { Flooding } \\
\text { times }\end{array}$ & $\begin{array}{c}\text { Duration } \\
(\text { days })\end{array}$ \\
\hline 1999 & 472 & $38 \cdot 45$ & $359 \cdot 4$ & 0 & 0 \\
1981 & 630 & 96.62 & $359 \cdot 5$ & 3 & 34 \\
1973 & 540 & 62.32 & $359 \cdot 1$ & 2 & 26 \\
\hline
\end{tabular}

${ }^{a}$ The threshold stage was estimated based on the river bank elevation taking the sea level as datum. event occurrence and calculate flood durations. Figure 7 shows that over-bank flooding times and durations for reconstructed flow regime in 1999 was three events and 27 days using daily river discharge of 1981, and two events and 10 days using daily river discharge of 1973 . These results verified our hypothesis that reduction in river discharge was the main driving force for variations in over-bank flooding dynamics. Note that there is some uncertainties associated with using a calibrated constant Chezy coefficient since cross-section boundary roughness change with river stages (Rupp and Smart, 2007; Warmink et al., 2007). Using a constant Chezy's coefficient may result in overestimate of water level at low discharge and underestimate water level at high discharge (Warmink et al., 2007). Therefore, we may have underestimated over-bank flooding events and duration while using daily discharges from 1973 and 1981, leading our conclusions to a more conservative side.

Causes of reduced river discharge. Reduced river discharge may result from climate changes such as increased temperature and decreased precipitation or human activities such as dam construction, water diversion and groundwater pumping (Poff et al., 1997). From 1955 to 1983 (Figure 8), reservoir capacity along the Wei River upstream of Lintong gauge station increased by $1600 \%\left(53 \times 10^{7} \mathrm{~m}^{3}\right.$ to $\left.854 \times 10^{7} \mathrm{~m}^{3}\right)$, and irrigated areas increased by $1200 \%\left(3.5 \times 10^{4}\right.$ ha to $43.2 \times$ $\left.10^{4} \mathrm{ha}\right)$. Major human disturbances happened between 1970 and 1985 because $90 \%$ of total reservoir capacity and $65 \%$ of total irrigated area in the Wei River basin were completed during this period (Figure 8). Construction and operation of reservoirs, irrigation projects, and groundwater pumping etc., have inevitably led to alterations in natural dynamics of the Wei River flow regime. These disturbances have eventually resulted in undesirable ecological effects such as threats to wildlife species (Song et al., 2007). Annual precipitation of the Wei River watershed above Lintong station showed a declining trend from 1951 to 2000 as shown in Figure 2. Wang et al. (2008) reported that precipitation is more influential than evapotranspiration on stream flow in the Loess Plateau region where our study site is located in (Figure 1).

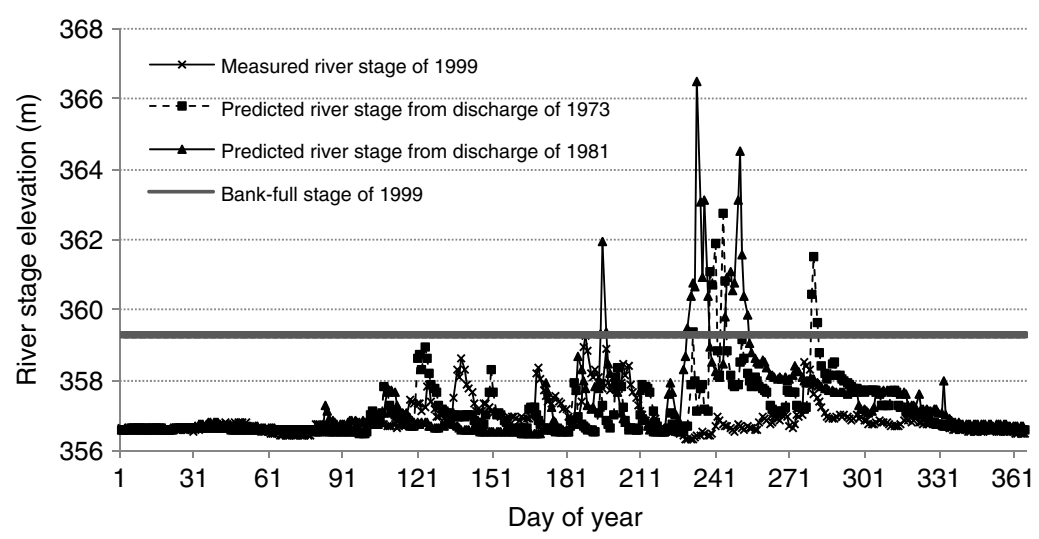

Figure 7. Simulated daily river stage at Gengzhen cross-section in 1999 using discharge of a wet year (1973) and a normal year (1981) 
Therefore, we considered annual precipitation decrease as the only factor while evaluating the impact of climate change on decreased runoff in the Wei River. In order to separate contributions of human activities and climate change, Pettit's test was used to detect change points of hydrological data series. These change points were used to determine periods over which double mass curves were constructed to interpret the relationship between annual precipitation and annual runoff of the Wei River. Results of Pettitt's tests are plotted in Figure 9. Two change points with maximum values of $\mathrm{k}(\mathrm{t})$ were detected as $1970(p=0.001)$ and $1985(p=0.005)$. Both change points were preceded by several years of rapid increase in reservoir capacity and irrigation areas (Figure 8). The results were consistent with our expectations considering the time lag in the impact of human activities over the large river basin. Zhang et al. (2008) studied the trends of stream flow in Loess Plateau area and found that change points in the area were between 1971 and 1985, which were close to our results.

The study period from 1951 to 2000 was divided into three periods: 1951-1970, 1971-1985, and 1986-2000. We assume the first period from 1951 to 1970 as a baseline period with limited human activity and climate change; the second period from 1971 to 1985 as a period of strong human influence and limited climate change; and the third period from 1986 to 2000 as a period with combined impacts of human activities and climate change. The mean annual precipitation of the

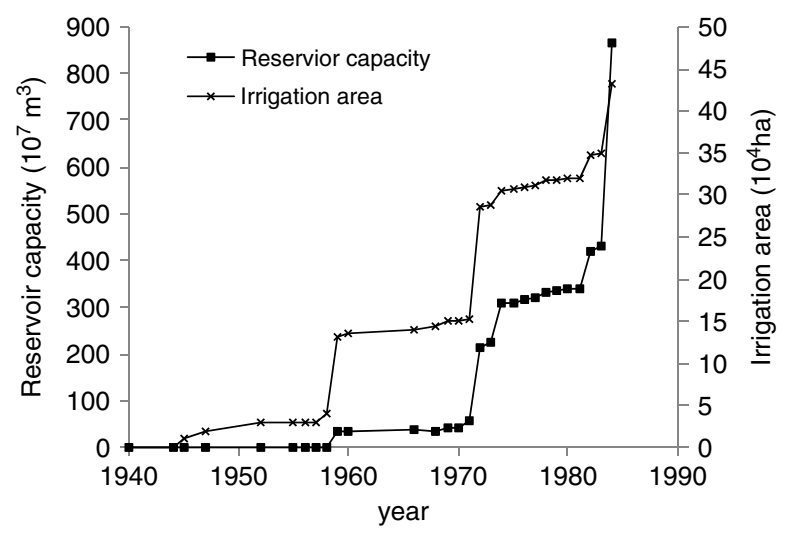

Figure 8. Changes in reservoir capacity and irrigation areas along Wei River upstream of Lintong gauge station

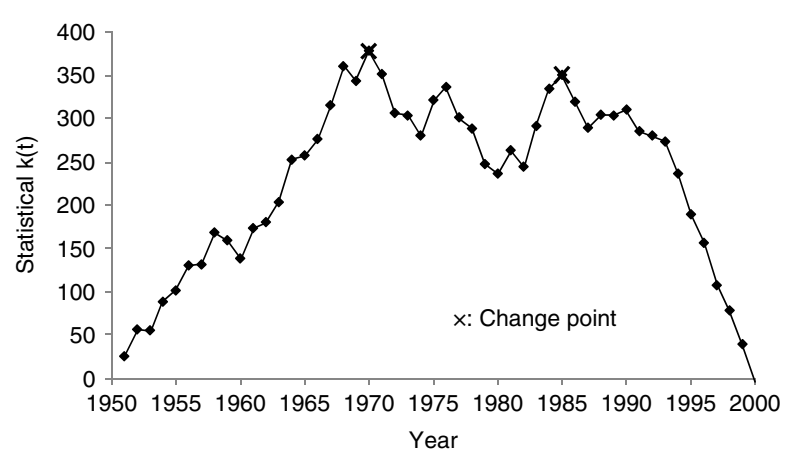

Figure 9. Pettitt's tests results on annual runoff for Wei River at Lintong gauge station second period was $638.3 \mathrm{~mm} / \mathrm{year}$, very close to the mean annual precipitation of $675.1 \mathrm{~mm} / \mathrm{year}$ in the baseline period; the mean annual precipitation of the third period was $504.4 \mathrm{~mm}$, which was about $21 \%$ lower than that in the baseline period. Figure 10 shows double mass curves for the three periods. All periods have a strong linear relationship between cumulative precipitation and cumulative runoff with correlation coefficients $\left(\mathrm{r}^{2}\right)$ of 0.997, 0.989, and 0.956, respectively (Figure 10). Runoff coefficients of the three periods, presented as slopes of lines in Figure 10, were 0.157, 0.123, and 0.105. The runoff coefficient for the third period from 1986 to 2000 was significantly lower than the other two slopes $(p<$ 0.05 ), indicating that lesser amounts of runoff would generated under same precipitation amount. Based on the linear relationships obtained for the double mass curves, the amount of 'natural' annual runoff during the third period can be estimated using the regression equation of the baseline period. Similarly, the annual runoff under 'pure' human disturbance can be obtained using the regression equation of the second period. Therefore, contributions of human activities and climate change to the reduced flow of the Wei River in the third period were separated and summarized in Table IV. Estimated separate contributions from human activities and climate change were $54.7 \%$ and $45.3 \%$, respectively for the third period from 1986 to 2000. This result is very close to the findings of Zhang et al. (2008), who concluded that human activities accounted for over 50\% reduction of annual runoff in the area of Loess Plateau.

Above analyses verified our hypotheses that a) the significant reduction of over-bank flooding events in Jingwei wetland was mainly caused by reduced river discharge and b) human impacts and climate change had almost equal contributions to the decline in river discharge. Separating the effects of human activities and climate change on river flow regime variations has always been a challenging task. Methods used in the present study are simple but results are comparable with other studies conducted in the same region.

\section{Implications for Jingwei riparian wetland restoration}

Loss of natural connectivity dynamics between rivers and riparian wetlands is a major factor for degradation

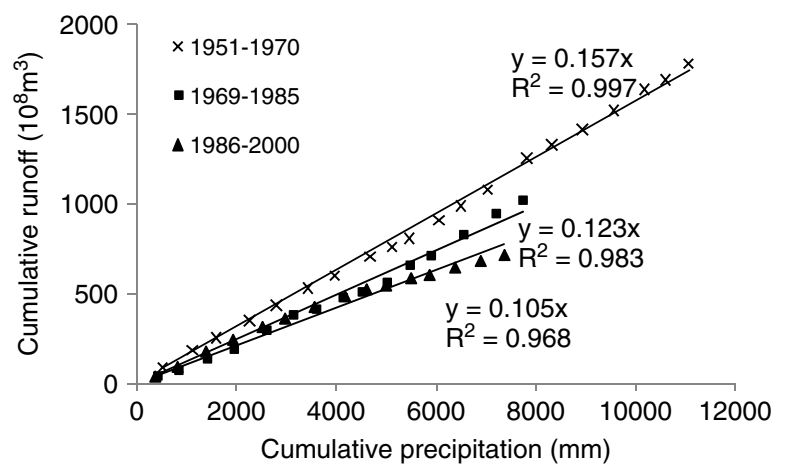

Figure 10. Double mass curves for annual precipitation and cumulative runoff of Wei River watershed above Lintong gauge from 1951 to 2000 
Table IV. Gross estimation of contribution from human activities and climate change to Wei River discharge reduction

\begin{tabular}{llcccrc}
\hline & $\begin{array}{c}\text { Regression } \\
\text { equation }\end{array}$ & $\begin{array}{c}\text { Measured } \\
\text { cumulative runoff }\end{array}$ & $\begin{array}{c}\text { Predicted cumulative } \\
\text { runoff }\end{array}$ & $\begin{array}{c}\text { Value under effect of } \\
\text { human activity }\end{array}$ & Contribution \\
\cline { 3 - 6 } & & & & Human & Climate \\
\hline $1951-1970$ & $y=0 \cdot 157 x$ & $1734 \cdot 0$ & $1734 \cdot 0$ & $1734 \cdot 0$ & 0 & 0 \\
$1986-2000$ & $y=0 \cdot 123 x$ & $1027 \cdot 07$ & $1230 \cdot 86^{\mathrm{a}}$ & $1027 \cdot 07$ & $203 \cdot 03$ & 0 \\
\hline
\end{tabular}

Note: Unit of runoff is $10^{8} \mathrm{~m}^{3}$.

a The predicted runoff means the cumulative runoff simulated using the equation of the baseline period 1951-1970.

$\mathrm{b}$ The cumulative runoff of period 1986-2000 was simulated using the equation of period of 1971-1985.

of riparian wetlands (Ward and Stanford, 1995; Davis and Froend, 1999; Middleton, 1999; Kingsford, 2000; Kingsford and Thomas, 2002). For Jingwei wetland discussed in this research paper, it is not the case. Our study indicated that significant changes in over-bank flooding dynamics first occurred during the 1990s. This, however, is not consistent with the timing of the wetland degradation that started in 1970s. We thus conclude that changing flooding regime in the riparian area is not the major cause of the wetland destruction; other human activities such as 'wasteland' reclamation on the floodplain and sand dredging on the river bank etc. (Tian, 2007) may have destroyed native vegetation and soil condition in the wetland, causing degradation of the riparian wetland.

Because of the significance of over-bank flooding on riparian wetlands, our study results have crucial implications in developing restoration and protection strategies for Jingwei wetland. A commonly accepted 'best practice' to restore riparian zones is reestablishing dynamic surface connectivity between rivers and riparian areas by restoring natural flow regimes of the river (Ward and Stanford, 1995; Poff et al., 1997; Middleton 1999). Our research showed that natural over-bank flooding regime of Jingwei riparian wetland has been altered significantly. Natural over-bank flooding dynamics indentified in our study is valuable for hydrologists, ecologists, engineers and policy makers to incorporate into their plans for wetland restoration and water resource management along the Wei River. We regarded over-bank flooding dynamics before 1970 as natural because there were limited disturbances from human activity and climate change then. Identified natural flooding regime has an annual flooding frequency of 2.2 (Figure 4) and duration of 5.3 days (Figure 5); over-bank flooding events usually occur between June and September and occasionally during late spring and late autumn (Figure 6). Li et al. (2008) indicated that the best sprouting and growing period for native wetland plants, such as reeds (Phragmites australis), is from May to July in semi-arid and semi-humid areas of China. Therefore, reduced flooding events during these months can negatively affect regeneration and survival of wetland plants in Jingwei riparian wetland. Considering the anthropogenic activities occurred before 1970 (Figure 8), our assumption on the 'baseline' period may be questioned (Figure 8). Based on our field surveys, the Jingwei wetland played an important role in maintaining regional water quality, plant diversity and productivity before 1970 s. Therefore, the identified natural over-bank flooding regime can be used as a guideline for developing engineering measures and water resources management strategies at the site with reasonable confidence. In addition, results from this research can be useful in setting up a realistic restoration goal to manage the river towards an ecological equilibrium and a less degraded state rather than attempting to recreate unachievable or even unknown historical natural conditions (Palmer et al., 2005).

Our study indicated that both local and regional factors are involved in the degradation processes of Jingwei wetlands. All these factors should be taken into account for successfully restoration of the riparian wetland. For instance, human activities and climate changes in the regional scale led to hydrological changes of the Wei River, which in turn altered hydrological condition of Jingwei riparian wetland. Human activities at local level such as land reclamation and sand dredging destroyed the original natural vegetation and soil in the wetland and accelerate wetland degradation processes. Therefore, comprehensive measures should be taken for development of wetland restoration plan and water resources allocation in the Wei River basin.

Considering the severe water resources shortage in the region, restoring hydrology of the Jingwei riparian wetland by inducing optimal over-bank flooding dynamics may be the best management practice for water resources management in the basin. However, flooding control remains to be the highest priority. The Wei River is prone to flooding because of its high elevation and sediment content. For instance, the flooding in the first seven months of 2003 affected an estimated people of 4.9 million, 46000 homes were destroyed and 676 fatalities were reported (Feng et al., 2004). Balancing potential conflicts between restoring natural river regime and flooding control is a great challenge for water resources management in the Wei River basin.

\section{CONCLUSION}

The present study showed that frequency and duration of over-bank flooding events have decreased significantly 
since 1990s in the Wei River in Shaanxi, China. Seasonal variations of over-bank flooding were represented by disappearing of flooding events in late springs and later autumns. Reduced flow discharge is the principal cause for changes in over-bank flooding dynamics, which is crucial for maintaining hydrology of the Jingwei riparian wetland. Both human activities and climate change have contributed to changes in flow regime of the Wei River. 'Natural' over-bank flooding dynamics indentified in this research may help design practical goals for restoration of the degraded Jingwei wetland. Future research should focus on how to implement flood control operations along the Wei River to allow flash over-bank flooding to occur in Jingwei riparian wetland.

\section{ACKNOWLEDGEMENTS}

This research was supported by the National Natural Science Foundation of China (Grant no. 50939004), and Xi' an University of Technology, China. Thanks to Drs M R Burchell and K L Bass in the North Carolina State University for their help with English of this paper.

\section{REFERENCES}

Amoros C, Bornette G. 2002. Connectivity and biocomplexity in waterbodies of riverine floodplains. Freshwater Biology 47: 761-776.

Bledsoe BP, Shear TH. 2000. Vegetation along hydrologic and edaphic gradients in North Carolina coastal plain creek bottom and implications for restoration. Wetlands 20: 126-147.

Castro JM, Jackson PL. 2001. Bank full discharge recurrence intervals and regional hydraulic geometry relationships. Journal of the American Water Resources Association 37(5): 1249-1262.

Davis JA, Froend R. 1999. Loss and degradation of wetlands in southwestern Australia: underlying causes, consequences and solutions. Wetlands Ecology and Management 7: 13-23.

Demarée GR. 1990. An indication of climatic change as seen from the rainfall data of a Mauritanian station. Theoretical and Applied Climatology 42: 139-147.

Deng AJ, Guo QC. 2006. Characteristics and evolution mechanism of cross sections along the Lower Weihe River. Journal of Sediment Research 5: 33-39. (in Chinese).

Feng PL, Shi CW, Zhng GL. 2004. Analysis of "2003” Weihe River flood and its disaster mitigation measures. Journal of China Institute of Water Resources and Hydropower Research 2(1): 44-49. (in Chinese).

Fennessy MS, Mitsch WJ. 2001. Effects of hydrology on spatial patterns of soil development in created riparian wetlands. Wetlands Ecology and Management 9: 103-120.

Fink DF, Mitsch WJ. 2007. Hydrology and nutrient biogeochemistry in a created river diversion oxbow wetland. Ecological Engineering 30: 93-102.

Galat DL, Fredrikson LH, Humburg DD, Bataille KJ, Bodie JR, Dohrenwend J, Gelwicks GT, Havel JE, Helmers DL, Hooker JB, Jones JR, Knowlton MF, Kubisiak J, Mazourek J, McCoplin AC, Renken RB, Semlitsch RD. 1998. Flooding to restore connectivity of regulated, large-river wetlands. BioScience 48: 721-733.

Gerhart PM, Gross RJ, Hochstein JI. 1992. Fundamentals of Fluid Mechanics, 2nd edn. Addison-Wesley: Reading; 983.

Hamilton SK, Sippel SJ, Melack JM. 1995. Oxygen depletion and carbon and methane production in waters of the Pantanal wetland of Brazil. Biogeochemistry 30: 115-141.

Harold LL, Michael AE. 2006. Applicability of the flood-pulse concept in a temperate floodplain river ecosystem: thermal and temporal components. Regulated Rivers: Research \& Management 22: 543-553. DOI: $10.1002 /$ rra.921.

Harman WA, Jennings GD, Patterson JM, Clinton DR, Slate LO, Jessup JR, Everhart AG, Smith RE. 1999. Bankfull Hydraulic Geometry Relationships for North Carolina Streams. In: AWRA Wildland Hydrology Proceedings, Olsen DS, Potyondy JP (Editors). AWRA Summer Symposium, Bozeman, Montana, pp. 401-408.
Heiler G, Hein T, Schiemer F, Bornette G. 1995. Hydrological connectivity and flood puses as the central aspects for the integrity of a river-floodplain system. Regulated Rivers: Research \& Management 11: $351-361$.

Herweg K, Ludi E. 1999. The performance of selected soil and water conservation measures - case-studies from Ethiopia and Eritrea. Catena 36: 99-114.

Huo Z, Feng S, Kang S, Li W, Chen S. 2008. Effect of climate change and water-related human activities on annual stream flows of the Shiyang river basin in arid north-west China. Hydrological Processes 22: $3155-3167$

Jia Z, Luo W, Zhou X, Liu X. 2004. Study on hydrological dynamics and formation criteria of wetlands. Journal of Hydraulic Engineering 6: 27-32. (in Chinese).

Junk WJ, Wantzen KM. 2004. The flood pulse concept: new aspects, approaches, and applications - an update. In Proceedings of the Second International Symposium on the Management of Large Rivers for Fisheries, vol. 2, Welcomme RL, Petr T (eds). Food and Agriculture Organization \& Mekong River Commission. FAO Regional Office for Asia and the Pacific RAP Publication 2004/16: Bangkok; 117-149.

Junk WJ, Bayley PB, Sparks RE. 1989. The flood pulse concept in riverfloodplain systems. Canadian Special Publication of Fisheries and Aquatic Science 106: 110-127.

Kingsford RT. 2000. Ecological impacts of dams, water diversions and river management on floodplain wetlands in Australia. Austral Ecology 25: $109-127$.

Kingsford RT. 2003. Social, institutional and economic drivers for water resource development - a case study of the Murrumbidgee River, Australia. Aquatic Ecosystem Health and Management 6: 69-79.

Kingsford RT, Thomas RF. 2002. Use of satellite image analysis to track wetland loss on the Murrumbidgee River floodplain in arid Australia, 1975-1998. Water Science and Technology 45: 45-53.

Lang M, Ouarda TBMJ, Bobée B. 1999. Towards operational guidelines for over-threshold modeling. Journal of Hydrology 225: 103-117.

Leyer I. 2005. Predicting plant species' responses to river regulation: the role of water level fluctuations. Journal of Applied Ecology 42: $239-250$.

Li X, Hu S, Li Y. 2008. Study on the reed root distribution and soil water dynamics under Phragmites arid area. Acta Prataculturae Sinica 2: 85-91. (in Chinese).

Lørup JK, Refsgaard JC, Mazvimavi D. 1998. Assessing the effect of land use change on catchment runoff by combined use of statistical tests and hydrological modelling: case studies from Zimbabwe. Journal of Hydrology 205: 147-163.

Lu X, Zhang X, Wang F. 2008. The concentrations of natural radionuclides in sediment of the Wei River of China. Environmental Geology 53: 1475-1481.

Magee TK, Kentula ME. 2005. Response of wetland plant species to hydrologic conditions. Wetlands Ecology and Management 13: $163-181$.

Middleton B. 1999. Wetland Restoration: Flood Pulsing and Disturbance Dynamics. John Wiley \& Sons Ltd: New York.

Mitsch WJ, Gosselink JG. 2000. Wetlands, 3rd edn. John Wiley \& Sons, Inc: New York; 582.

Molles MCJ, Crawford CS, Ellis LM, Valett HM, Dahm CN. 1998. Managed flooding for riparian ecosystem restoration. BioScience 48 : 749-756.

Naiman RJ, Décamps H. 1997. The ecology of interfaces: riparian zones. Annual Review of Ecology and Systematics 28: 621-658.

Navratil O, Albert MB, Hérouin E, Gresillon JM. 2006. Determination of bankfulldischarge magnitude and frequency: comparison of methods on 16 gravel-bed river reaches. Earth Surface Processes and Landforms 31: $1345-1363$.

Page K, Read A, Frazier P, Mount N. 2005. The effect of altered flow regime on the frequency and duration of bankfulldischarge: Murrumbidgee river, Australia. Regulated Rivers: Research \& Management 21: 567-578.

Palmer MA, Bernhardt ES, Allan JD, Lake PS, Alexander G, Brooks S, Carr J, Clayton S, Dahm CN, Follstad Shah J, Galat DL, Loss SG, Goodwin P, Hart B, Hassett DD, Jenkinson R, Kondolf GM, Lave R, Meyer JL, O’Donnell TK, Pagano L, Sudduth E. 2005. Standards for ecologically successful river restoration. Journal of Applied Ecology 42: $208-217$.

Petit F, Pauquet A. 1997. Bankfulldischarge recurrence interval in gravelbed rivers. Earth Surface Processes and Landforms 22: 685-693.

Pettitt AN. 1979. A non-parametric approach to the change point problem. Applied Statistics 28: 126-135.

Pettit NE, Froend RH, Davies PM. 2001. Identifying the natural flow regime and the relationship with riparian vegetation for two contrasting 
western Australian rivers. Regulated Rivers: Research and Management 17: $201-215$.

Petts GE, Gurnell AM. 2005. Dams and geomorphology-research progress and future directions. Geomorphology 71: 27-47.

Poff NL, Allan JD, Bain MB, Karr JR, Prestegaard KL, Richter BD, Sparks RE, Stromberg JC. 1997. The natural flow regime. Bioscience 47: 769-784.

Pringle CM. 2001. Hydrologic connectivity and the management of biological reserves: a global perspective. Ecological Applications 11: 981-998.

Puckridge JT, Sheldon F, Walker KF, Boulton AJ. 1998. Flow variability and the ecology of large rivers. Marine and Freshwater Research 49: $55-72$.

Rea N, Ganf GG. 1994. How emergent plants experience water regime in a Mediterranean-type wetland. Aquatic Botany 49: 117-136.

Reckendorfer W, Baranyi C, Funk A, Schiemer F. 2006. Floodplain restoration by reinforcing hydrological connectivity: expected effects on aquatic mollusc communities. Journal of Applied Ecology 43: 474-484.

Robertson AI, Bacon P, Heagney G. 2001. The responses of floodplain primary production to flood frequency and timing. Journal of Applied Ecology 38: 126-136.

Rupp DE, Smart GM. 2007. Comment on "Flow resistance equations without explicit estimation of the resistance coefficient for coarsegrained rivers" by Raúl López, Javier Barragán, and M. Ángels Colomer. Journal of Hydrology 346: 174-178.

Schiemer F, Baumgartner C, Tockner K. 1999. Restoration of floodplain rivers: the Danube restoration project. Regulated Rivers: Research \& Management 15: 231-244.

Searcy JK, Hardison CH. 1960. Double-mass curves In "Flow-Duration Curves," U.S. Geological Survey, Water-Supply Paper 1541-A, Searcy JK (ed). GPO: Washington, DC; 66.

Song XJ, Xu ZX, Liu CM, Li HE. 2007. Ecological and environmental instream flow requirements for the the Wei River-the largest tributary of the Yellow River. Hydrological Processes 21: 1066-1073.

Shi NH. 1999. Change of the Rivers in Yellew catchment and administration. Shaanxi People Press: Xi'an; 315-320.

Sweet WV, Geratz JW. 2003. Bankfull hydraulic geometry relationships and recurrence intervals for North Carolina's coastal plain. Journal of the American Water Resources Association 39: 561-871.
Tian S. 2007. Preliminary study on the hydrological relationship between river and reparian wetland. Master thesis, Xi'an University of Technology, Xi'an, China.

Tian S, Luo W, Jia Z. 2008. Effect of overbank flooding on hydrology restoration of the Jingwei wetland. Journal of Hydraulic Engineering 39: 115-120. (in Chinese).

Tockner K, Pennetzdorfer D, Reimer N, Schiemer F, Ward JV. 1999 Hydrological connectivity and the exchange of organic matter and nutrients in a dynamic river floodplain system (Danube, Austria). Freshwater Biology 41: 521-536.

Tockner K, Malard F, Ward JV. 2000. An extension of the flood pulse concept. Hydrological Processes 14: 2861-2883.

USWRC. 1976. Guidelines for determining flood flow frequency. United States Water Resources Council,, Hydrol. Comm. Bull.17: Washington, DC; 73.

Victoria RL, Martinelli LA, Moraes JM, Ballester MV, Krusche A, Pellegrino G, Almeida RMB, Richey JE. 1998. Surface air temperature variations in the Amazon region and its borders during this century. Journal of Climate 11: 1105-1110.

Walker KF, Sheldon F, Puckridge JT. 1995. A perspective on dryland river ecosystems. Regulated Rivers: Research and Management 11: $85-104$.

Wang H, Xu D, Liang Z. 2004. Effect of variationsvariationsin flow and sediment to siltation and profile in the lower Weihe River. Journal of sediment research 6: 27-30. (in Chinese).

Wang S, Zhang Z, Sun G, McNulty SG, Zhang H, Li J, Zhang M. 2008 Long-term streamflow response to climatic variability in the Loess Plateau, China. Journal of the American Water Resources Association (JAWRA) 44(5): 1098-1107. DOI: 10.1111/j.1752-1688.2008.00242.x.

Ward JV, Stanford JA. 1995. Ecological connectivity in alluvial river ecosystems and its disruption by flow regulation. Regulated Rivers: Research and Management 11(1): 105-119.

Warmink JJ, Booij MJ, van der Klis H, Hulscher SJMH. 2007. Uncertainty in water level predictions due to various calibrations. In Proc. Of CAIWA 2007, Pahl-Wostl C (ed). Basel: Switserland; 1-18.

Wurster FC, Cooper DJ, Sanford WE. 2003. Stream/aquifer interactions at Great Saad Dunes National Monument, Colorado: influences on interdunal wetland disappearance. Journal of Hydrology 271: 77-100.

Zhang X, Zhang L, Zhao J, Rustomji P, Hairsine P. 2008. Responses of streamflow to changes in climate and land use/cover in the Loess Plateau, China. Water Resources Research 44: W00A07. DOI:10.1029/2007WR006711. 